\title{
Beneficiation of an Indian non-coking coal by column flotation
}

\author{
N. Vasumathi ${ }^{1}$ T. V. Vijaya Kumar ${ }^{1}$ S. Ratchambigai $^{1} \cdot$ S. Subba Rao ${ }^{1}$ S. Prabhakar ${ }^{1}$ G. Bhaskar Raju ${ }^{1}$
}

Received: 27 October 2015/Revised: 3 December 2015/Accepted: 23 February 2016/Published online: 8 June 2016

(C) The Author(s) 2016. This article is published with open access at Springerlink.com

\begin{abstract}
Beneficiation of non-coking coal is gaining ground in India. It not only reduces the volume of inert content to be transported to the power plant and also lowers the wear in the boiler houses. For special applications such as the fuel for integrated gasification combined cycle plant (IGCC), the ash content in the coal should preferably be below $15 \%$. Indian coals are characterized by high inter-grown ash content mainly due to 'drift origin' of Gondwana formation in Permian age. This warrants fine grinding of non-coking coal in order to liberate the ash forming minerals from coal macerals. A noncoking coal sample of vitrinite type from India was ground to $44 \mu \mathrm{m}\left(\mathrm{d}_{80}\right)$ and subjected to column flotation to improve its quality. The non-coking coal analyzing $34.6 \%$ ash, $26.2 \%$ volatile matter, $1.3 \%$ moisture and $37.9 \%$ fixed carbon could be upgraded to a concentrate/froth of $14.83 \%$ ash at $72.18 \%$ yield by optimizing collector and frother dosages and flotation column operating parameters, namely, froth depth, superficial feed velocity and superficial air velocity. The concentrate produced by this process is suitable as fuel for IGCC in coal-to-electricity route.
\end{abstract}

Keywords Non-coking coal $\cdot$ Washability $\cdot$ Beneficiation $\cdot$ Column flotation $\cdot$ Coal gasification

\section{Introduction}

Coal, accounting for $63 \%$ of the world's total energy content, is the world's most abundant fossil fuel resource. The world supply of crude oil and natural gas is limited and, at projected rate of exploitation is expected to be depleted within the next two or three decades. If worldwide economic development is to continue, alternate fuel resources (such as coal) need to be more fully exploited to meet the anticipated world energy requirement. India is in the threshold of techno-economic washing of coal. So far, large scale beneficiation was resorted to coking coals only for steel making purposes. Now, the stage is set to attract investors to take up beneficiation of non-coking coals also for power plants.

N. Vasumathi

vasumatisamy@gmail.com

1 CSIR-National Metallurgical Laboratory Madras Centre, CSIR Madras Complex, Taramani, Chennai 600 113, India
With a growing concern over energy security and sustainability, coupled with concerns about climate change and greenhouse gas emissions from coal combustion, the long term generation of coal based thermal power by India will require the use of cleaner coal and clean coal technologies (CCT). Coal beneficiation is the first and most cost effective step towards satisfying this requirement (Yenigalla 2013). Beneficiation of non-coking coal in India was not given due importance till last 10-12 years due to its low value or not able to meet the cost of the process (Misra et al. 2003). Studies conducted by the International Energy Agency have shown that $1 \%$ increase in ash (generally after passing the $10 \%$ ash level) results in a $1.2 \%-1.5 \%$ decrease in boiler availability and a decrease of $0.3 \%$ in boiler efficiency (Konar et al. 1997). To cut down the consumption of oil in existing oil-fired furnaces, coal-oil and coal-water mixture can be used for which low-ash coals recovered from non-coking coals by deep coal cleaning may be of great help. Coal-to-electricity route spans many promising technologies which include integrated gasification combined cycle plant (IGCC). 
Analysis of data on gasification process has shown that low ash coals perform better for IGCC. The percentage of reserves of inferior non-coking coal is $71 \%$ of total Indian non-coking coal reserves. Therefore, the share of inferior coal production will further increase.

Most Indian coals have a considerable proportion of fixed ash due to 'drift origin' of Gondwana formation in Permian age (Khoury 1981). Most of the thick seams are banded in nature. The bands themselves are usually carbonaceous in nature and very rarely consist of pure sandstones (Mukherjee et al. 1982). These coals are difficult to clean by conventional methods. For applications such as IGCC, these coals need to be ground finer in order to liberate these finely disseminated or inter grown foreign matter. Most of the physical separation techniques have limitations in terms of efficiency of separation at this finer size of grinding. Flotation is the only versatile process in use for fine coal processing in India. Conventional mechanical flotation cells cannot remove all the liberated mineral matter in a single stage. If conventional cells are used, the entrained particles can be removed by refloating the concentrate several times but the cost of multi-stage flotation is often prohibitive. Of late, column flotation has been found to be superior to conventional cells because of a more extended collection zone and improved particle bubble contact efficiency. Keeping this in view, investigations were carried out on a non-coking sample to reduce the ash content from $34.60 \%$ to $15 \%$ in a flotation column.

\section{Materials and methods}

\subsection{Material characterization}

The non-coking coal used in this study was sourced from North Karanpura (Jharkhand, India). The following coal characterization studies were carried out preceding the flotation studies.

\subsection{Proximate analysis}

The proximate analysis of the coal sample is as shown in Table 1. It could be observed that the high ash content in this coal warrants processing for its utilization.

Table 1 Proximate analysis (air dry basis) of non coking-coal sample $(\%)$

\begin{tabular}{llll}
\hline$A_{\text {ad }}$ & $M_{\text {ad }}$ & $V_{\text {ad }}$ & $\mathrm{FC}_{\text {ad }}$ \\
\hline 34.6 & 1.3 & 26.2 & 37.9 \\
\hline
\end{tabular}

\subsection{Petrographic analysis}

The petrographic analysis of the coal sample was carried out and the results are as shown in Table 2. Its mean maximum reflectance was found to be $0.71 \%$.

The values in parenthesis are on 'mineral-free' basis. Earlier researchers established the following floatability order of the petrographic components (Brady and Gauger 1940; Arnold and Aplan 1989; Gosiewska et al. 2002; Ding 2009).

Vitrinite $>$ Exinite $>$ Inertinite $>$ Inorganic mineral matter

This floatability order indicates the theoretical possibility of the separation of different petrographic components of the present coal sample.

\subsection{Size analysis}

The size analysis of coal was carried out and the results are as shown in Table 3.

From the above table, it is clear that ash is distributed predominantly in the size range of $-6+0.5 \mathrm{~mm}$. The percent ash distribution value in the individual size fractions in this size range is around $20 \%$. The coal was further subjected to crushing in rolls for liberation of ash forming minerals.

\subsection{Washability study}

The coal was sieved at $0.5 \mathrm{~mm}$ and the $-0.5 \mathrm{~mm}$ fraction of coal was segregated. The $+0.5 \mathrm{~mm}$ coal was subjected to heavy media separation (HMS) in successive baths of increasing specific gravity. The medium of desired density is obtained by using organic liquid mixtures of bromoform, tetrachloroethylene and benzene. From the HMS study, the washability curves are plotted as shown in Fig. 1. From these, it is evident that $70 \%$ of the coal size fraction $(-6+0.5 \mathrm{~mm})$ could be obtained as float with $15 \%$ ash content by subjecting it for heavy medium separation at 1.70 specific gravity. The rejects amount to 30 wassaying $70 \%$ ash (as shown in black dotted lines).

\subsection{Flotation column}

The automated laboratory flotation column with an internal diameter of $75 \mathrm{~mm}$, designed and developed by CSIRNML Madras Centre was used in the present study to know the effect of its operating parameters on the process. The schematic details of laboratory column were shown in 
Table 2 Petrographic analysis of non-coking coal sample (\%)

\begin{tabular}{lllll}
\hline Vitrinite & Semi-vitrinite & Liptinite & Inertinite & Mineral matter \\
\hline $38.7(46.5)$ & $0.1(0.2)$ & $11.9(14.4)$ & $32.4(38.9)$ & 16.9 \\
\hline
\end{tabular}

Table 3 Size analysis of coal $\left(\mathrm{d}_{80}: 2108 \mu \mathrm{m}\right)$

\begin{tabular}{cccc}
\hline Size $(\mathrm{mm})$ & $\begin{array}{l}\text { Weight } \\
\text { retained }(\%)\end{array}$ & $A_{\text {ad }}(\%)$ & $\begin{array}{l}\text { Ash } \\
\text { distribution }(\%)\end{array}$ \\
\hline+6 & 1.00 & 39.12 & 1.14 \\
$-6+2.8$ & 27.52 & 24.93 & 20.00 \\
$-2.8+1.68$ & 22.82 & 31.25 & 20.79 \\
$-1.68+0.85$ & 25.17 & 38.16 & 28.00 \\
$-0.85+0.5$ & 14.43 & 46.25 & 19.46 \\
$-0.5+0.212$ & 6.71 & 39.18 & 7.66 \\
-0.212 & 2.35 & 43.08 & 2.95 \\
\hline
\end{tabular}

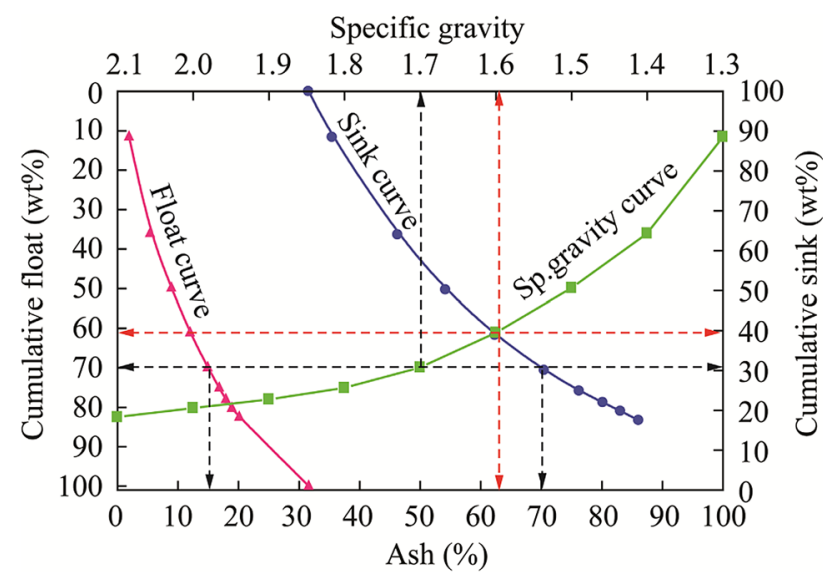

Fig. 1 Washability curves for $-6+0.5 \mathrm{~mm}$ fraction of coal

Fig. 2. Electronically controlled metering pumps were used to feed and discharge the slurry. Slurry/froth interface was maintained using differential pressure transmitter (DPT). The output signal of the DP cell was looped with the stroke controller of the tailings pump so that the pumping rate could be automatically varied to maintain the interface level at a fixed froth depth. Sintered ceramic tube air sparger is used with $30 \%$ porosity. Purge rotameter with a differential pressure regulator was used to control the flow of air to the column from a compressor. The column was filled with water and stabilized at required froth depth. The coal slurry at $\sim 10 \%$ solids by weight was conditioned initially with diesel (collector) in a conditioner for $3 \mathrm{~min}$. In the second stage, MIBC (frother) was added and conditioned for another $3 \mathrm{~min}$. This slurry was pumped to the column. The column was allowed to run for a minimum period of 3-4 residence times. Samples were drawn under near-steady state conditions. Both the process parameters and column operating conditions were recorded before collecting the samples. Samples were analyzed for ash content by standard method.

\section{Results and discussion}

Mechanized coal mining techniques generate large amount of fine particles that have to be recovered in coal washing plants. Fine coal processing has always been a problematic and costlier than the cleaning of coarse coal (Andrew Mohns 1997). Froth flotation technique is an effective and best available technique for cleaning fine coal with particle size less than approximately $0.5 \mathrm{~mm}$ (Bensley and Nicol 1985; Yoon et al. 2002; Koca et al. 2010). Froth flotation, which exploits the difference in surface properties of minerals, is recognized as an efficient method for coal cleaning and processing of minerals. The efficiency in separating the impurities from coal by flotation is basically determined by the relative hydrophobicity of coal and the associated gangue (Laskowski 2001; S Dey et al. 2013). In froth flotation, coal particles are often subjected to a suitable hydrocarbon oil treatment (Boylu and Laskowski 2007) to alter their hydrophobicity, enhance recovery, and/ or improve selectivity (Peng 1996). Conventionally, the collector used in most of the Indian coal washeries is diesel oil in combination with different frothers. The dosage of collector and frother has significant effect on flotation performance (Dey and Pani 2012). Therefore, optimization of grind, collector and frother dosages was carried out followed by that of the operating parameters of flotation column.

\subsection{Grind optimization studies}

To study the maximum achievable separation of combustible material, the coal sample was subjected to stage crushing to obtain $-1.68 \mathrm{~mm}$ product which was then fed to the ball mill. A representative sample was drawn for particle size and ash analysis and results are tabulated as Table 4.

The above sample was subjected for wet grinding in a laboratory ball mill and the grind variation studies were carried out for various grinding times $(15,20,25,30$ and 


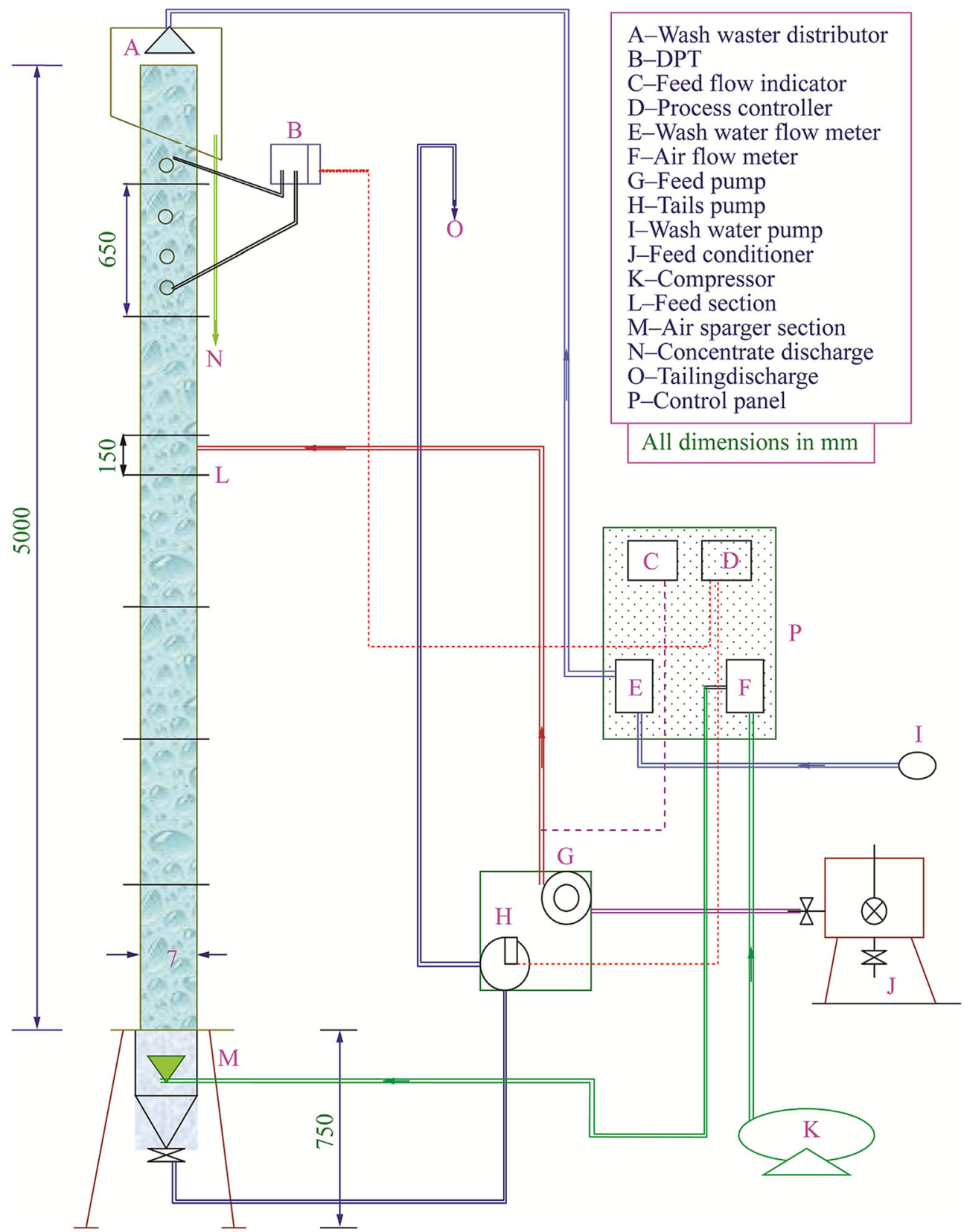

Fig. 2 Schematic diagram of CSIR-NML laboratory flotation column

$35 \mathrm{~min}$ ) at the pulp density of $60 \%$ solids by weight. Batch flotation tests were carried out on ground coal samples to optimize the 'mesh of grind' to recover the maximum combustibles. Bench scale flotation tests were performed in a D12 Denver Flotation Machine. The ground samples were subjected to flotation using diesel as collector and MIBC as frother. The combustible recovery (CR), ash rejection (AR) and efficiency index (EI) were calculated by using the following standard formulae (Vasumathi et al. 2013).
Table 4 Size analysis of feed to ball mill $\left(\mathrm{d}_{80}: 1102 \mu \mathrm{m}\right)$

\begin{tabular}{llll}
\hline Size $(\mu \mathrm{m})$ & Weight retained $(\%)$ & $A_{\text {ad }}(\%)$ & Ash distribution $(\%)$ \\
\hline+850 & 44.15 & 33.49 & 43.67 \\
$-850+425$ & 33.87 & 35.40 & 35.41 \\
$-425+212$ & 10.24 & 31.12 & 9.41 \\
$-212+106$ & 6.35 & 30.43 & 5.71 \\
-106 & 5.39 & 36.42 & 5.80 \\
\hline
\end{tabular}


$\% \mathrm{CR}=\left[\frac{M_{\mathrm{c}}\left(100-A_{\mathrm{c}}\right)}{M_{\mathrm{f}}\left(100-A_{\mathrm{f}}\right)}\right] \times 100$

$\% \mathrm{AR}=\left[1-\left(\frac{M_{\mathrm{c}} A_{\mathrm{c}}}{M_{\mathrm{f}} A_{\mathrm{f}}}\right)\right] \times 100$

$\mathrm{EI}=(\mathrm{CR}+\mathrm{AR})-100$

where $A_{\mathrm{c}}$ is the ash in concentrate, $\% ; A_{\mathrm{f}}$ is the ash in feed, $\% ; M_{\mathrm{c}}$ is the mass of concentrate and $M_{\mathrm{f}}$ is the mass of feed.

The results in Table 5 reveal that it is possible to obtain a froth/concentrate of $56 \%$ yield with less than $12 \%$ ash by flotation at $\mathrm{d}_{80}$ of $44 \mu \mathrm{m}$ corresponding to $30 \mathrm{~min}$. gGrind. Also, greater yield of $77 \%$ of froth with $19.7 \%$ ash content can be achieved without cleaning the rougher concentrate. Hence, it could be possible to obtain required $15 \%$ ash with maximum yield at this grind by optimizing the reagent dosages.

\subsection{Column flotation studies}

The collector and frother dosages and column operating parameters were optimized on laboratory scale flotation column. The grind of the coal was maintained the same $\left(\mathrm{d}_{80}: 44 \mu \mathrm{m}\right)$ in all the following tests.

\subsubsection{Optimization of collector (diesel) and frother $(M I B C)$ dosages}

The test conditions and the results on the effect of variation of diesel and MIBC dosages are given in the Tables 6 and 7 , respectively.

It could be observed that as the diesel dosage is increased from $2.55 \mathrm{~kg} / \mathrm{t}$ to $3.51 \mathrm{~kg} / \mathrm{t}$, the yield of the froth increased from $73.94 \%$ to $88.78 \%$ with ash in it increasing from $16.78 \%$ to $21.35 \%$. At the same time, efficiency index of separation decreases from 54.90 to 30.18. This could be attributed to the non-selectivity of diesel at higher dosages and physical entrainment/entrapment of ash forming minerals in the froth resulting in higher yield and ash content in the froth.

The dosage of frother plays vital role as it affects the bubble size distribution and mean bubble size. In flotation, the bubble is the driving force and it determines the separation efficiency. The flotation results at various MIBC dosages and at a constant diesel dosage are presented in Table 7. The results clearly indicate that MIBC plays very important role in coal flotation. At constant diesel dosage, flotation concentrate yield increased as the MIBC dosage increased.

Table 5 Flotation of coal at different grinding times (roughing followed by cleaning)

\begin{tabular}{|c|c|c|c|c|c|c|}
\hline Grinding time (min) & Product & Yield (\%) & $A_{\mathrm{ad}}(\%)$ & $\mathrm{CR}(\%)$ & $\operatorname{AR}(\%)$ & EI \\
\hline \multirow[t]{4}{*}{15} & F C & 8.31 & 5.91 & 11.65 & 98.51 & 10.16 \\
\hline & Cl.2-T & 33.85 & 11.50 & & & \\
\hline & Cl.1-T & 34.46 & 34.61 & & & \\
\hline & $\mathrm{P} \mathrm{T}$ & 23.38 & 71.05 & & & \\
\hline \multirow[t]{3}{*}{20} & F C & 51.51 & 13.88 & 68.95 & 79.96 & 48.91 \\
\hline & Cl.T & 28.43 & 45.11 & & & \\
\hline & $\mathrm{P} \mathrm{T}$ & 20.07 & 78.22 & & & \\
\hline \multirow[t]{3}{*}{25} & F C & 42.67 & 12.56 & 57.19 & 84.59 & 41.78 \\
\hline & $\mathrm{Cl} \mathrm{T}$ & 31.67 & 37.27 & & & \\
\hline & $\mathrm{P} \mathrm{T}$ & 25.67 & 68.59 & & & \\
\hline \multirow[t]{3}{*}{30} & F C & 56.10 & 11.77 & 72.99 & 79.49 & 52.48 \\
\hline & $\mathrm{Cl} \mathrm{T}$ & 20.91 & 41.08 & & & \\
\hline & $\mathrm{P} \mathrm{T}$ & 23.00 & 73.90 & & & \\
\hline \multirow[t]{3}{*}{35} & $\mathrm{~F} \mathrm{C}$ & 51.86 & 12.31 & 68.40 & 80.95 & 49.35 \\
\hline & $\mathrm{Cl} \mathrm{T}$ & 26.10 & 42.09 & & & \\
\hline & $\mathrm{P} T$ & 22.04 & 73.24 & & & \\
\hline
\end{tabular}

Note FC final concentrate, $C l T$ cleaner tailings, $P T$ primary tailings, diesel is $2.49 \mathrm{~kg} / \mathrm{t}, \mathrm{MIBC}$ is $0.66 \mathrm{~kg} / \mathrm{t}$, head ash of coal is $34.60 \%$ 
Table 6 Effect of diesel on column flotation of coal

\begin{tabular}{|c|c|c|c|c|c|}
\hline Diesel (kg/t) & Product & Yield $(\%)$ & Ash (\%) & Ash distribution (\%) & EI \\
\hline \multirow[t]{2}{*}{2.55} & Concentrate & 73.94 & 16.78 & 37.31 & 54.9 \\
\hline & Tailings & 26.06 & 80.00 & 62.69 & \\
\hline \multirow[t]{2}{*}{2.87} & Concentrate & 78.10 & 17.34 & 43.25 & 53.1 \\
\hline & Tailings & 21.90 & 81.14 & 56.75 & \\
\hline \multirow[t]{2}{*}{3.19} & Concentrate & 77.66 & 21.28 & 50.97 & 39.52 \\
\hline & Tailings & 22.34 & 71.17 & 49.03 & \\
\hline \multirow[t]{2}{*}{3.51} & Concentrate & 88.78 & 21.35 & 67.13 & 30.18 \\
\hline & Tailings & 11.22 & 82.72 & 32.87 & \\
\hline
\end{tabular}

Note MIBC dosage is $0.65 \mathrm{~kg} / \mathrm{t}$, froth depth is $600 \mathrm{~mm}$, superficial air velocity is $0.78 \mathrm{~cm} / \mathrm{s}$, superficial feed velocity is $0.57 \mathrm{~cm} / \mathrm{s}$, head ash of coal is $34.60 \%$

Table 7 Effect of MIBC on column flotation of coal

\begin{tabular}{llllll}
\hline MIBC $(\mathrm{kg} / \mathrm{t})$ & Product & Yield $(\%)$ & $A_{\text {ad }}(\%)$ & Ash distribution $(\%)$ \\
\hline 0.33 & Concentrate & 53.46 & 13.26 & 23.24 & 76.76 \\
& Tailings & 46.54 & 50.30 & 47.91 & 43.48 \\
0.49 & Concentrate & 78.26 & 21.31 & 52.09 & 46.60 \\
& Tailings & 21.74 & 83.40 & 53.40 & 46.56 \\
0.57 & Concentrate & 76.11 & 21.82 & 79.65 & 67.13 \\
& Tailings & 23.89 & 21.35 & 32.87 & 30.18 \\
\hline
\end{tabular}

Note Diesel dosage is $2.87 \mathrm{~kg} / \mathrm{t}$, froth depth is $600 \mathrm{~mm}$, superficial air velocity is $0.78 \mathrm{~cm} / \mathrm{s}$, superficial feed velocity is $0.57 \mathrm{~cm} / \mathrm{s}$, head ash of coal is $34.60 \%$

\subsection{Optimization of column operating parameters}

The following column parameters namely air flow rate, feed flow rate, froth depth, wash water and \% solids of feed were optimized for non-coking coal flotation.

\subsubsection{Effect of air flow rate}

Generally, superficial air velocity should be as large as possible to ensure a high throughput. At the same time, if the superficial air velocity is too high, the flow pattern will be disturbed and there is every possibility to lose bubbly swarm. It is to be noted that column should operate in a bubbly flow regime, where gas hold-up varies linearly with air rate. A proper combination of gas rate and bubble size will generally provide a gas holdup in the flotation pulp in the range of $15 \%-18 \%$.

The effect of superficial air rate on the flotation of coal is presented in Table 8. It is observed that as the superficial air rate increases there is no increase in the clean coal yield. But at higher superficial air rates the ash content in clean coal decreased marginally. This may be due to the reduction in gangue entrainment. The effect of superficial air rate on entrainment in froth may be explained as follows: the ash content in the clean coal is reduced at higher superficial air velocity because of increase in the bubble size in the froth zone. In the present investigation it was observed that the superficial air velocity of $0.78 \mathrm{~cm} / \mathrm{s}$ was found to be optimum to obtain better grade and recovery.

\subsubsection{Effect of feed flow rate}

Change in feed flow rate usually affects grade and recovery. In the case of coal flotation, the increase in volumetric feed flow rate results in decrease of residence time of slurry which will affect the recovery. Enough residence time is to be maintained so that entire coal will be collected and separated. Feed flow velocities were varied from 0.33 to $0.87 \mathrm{~cm} / \mathrm{s}$ by manipulating the speed of the variable 
Table 8 Effect of air rate on column flotation of coal

\begin{tabular}{lllll}
\hline $\begin{array}{l}\text { Superficial air } \\
\text { velocity }(\mathrm{cm} / \mathrm{s})\end{array}$ & Product & Yield $(\%)$ & Ash $(\%)$ & Ash distribution $(\%)$ \\
\hline 0.39 & Concentrate & 78.63 & 20.14 & 46.88 \\
& Tailings & 21.37 & 83.96 & 53.12 \\
0.59 & Concentrate & 77.95 & 21.72 & 46.66 \\
& Tailings & 22.05 & 87.79 & 53.34 \\
0.78 & Concentrate & 78.10 & 17.34 & 43.25 \\
& Tailings & 21.90 & 81.14 & 56.75 \\
0.98 & Concentrate & 73.14 & 18.74 & 39.31 \\
& Tailings & 26.86 & 78.77 & 60.69 \\
\hline
\end{tabular}

Note Diesel dosage is $2.87 \mathrm{~kg} / \mathrm{t}$, MIBC dosage is $0.65 \mathrm{~kg} / \mathrm{t}$, froth depth is $600 \mathrm{~mm}$, superficial feed velocity is $0.57 \mathrm{~cm} / \mathrm{s}$, head ash of coal is $34.60 \%$

frequency driven feed pump and the results were presented in Table 9.

As the superficial feed velocity increases, generally the weight recovery would decrease owing to the decrease in pulp residence time. On the other hand the quality of the concentrate generally increases due to less residence time of froth in the froth zone. From the results it is observed that the yield of clean coal is not much affected by increasing the superficial feed velocity which may be due to the natural floatability of coal. But at higher feed velocities, the ash content is increased in the clean coal because of less residence time of froth in the cleaning zone. Generally, good coal doesn't require larger residence times, but in the present case, the quality of clean coal is better at higher residence time i.e., at feed velocity of $0.41 \mathrm{~cm} / \mathrm{s}$. The calculated residence time at this feed velocity is about $18-20 \mathrm{~min}$.

\subsubsection{Effect of froth depth}

Floatability characteristics are also another factor which decides the height of the flotation zone. If the material is having higher floatability like graphite and coal, the froth height increases and does not affect much on yield but simultaneously the concentrate grade increases as demonstrated by the present studies. Further, it has been seen that by increasing the froth depth, the entrained gangue minerals in the concentrate reduce significantly due to coalescence of bubbles, positive bias water and reduction of feed water in the concentrate. Experiments were conducted at different froth depths ranging from $500 \mathrm{~mm}$ to $900 \mathrm{~mm}$ and the results obtained were presented in Table 10. The rejection of entrained particles, in this case, inorganic ash forming minerals, depends on froth depth. Due to high superficial air and feed velocities, fine and ultra fine sized

Table 9 Effect of Feed velocity on column flotation of coal

\begin{tabular}{|c|c|c|c|c|c|}
\hline $\begin{array}{l}\text { Superficial feed } \\
\text { velocity }(\mathrm{cm} / \mathrm{s})\end{array}$ & Product & Yield (\%) & $A_{\mathrm{ad}}(\%)$ & Ash distribution (\%) & EI \\
\hline \multirow[t]{2}{*}{0.33} & Concentrate & 80.39 & 17.78 & 48.57 & 45.10 \\
\hline & Tailings & 19.61 & 77.18 & 51.43 & \\
\hline \multirow[t]{2}{*}{0.41} & Concentrate & 79.58 & 16.99 & 45.56 & 48.39 \\
\hline & Tailings & 20.42 & 79.11 & 54.44 & \\
\hline \multirow[t]{2}{*}{0.49} & Concentrate & 76.67 & 18.41 & 43.23 & 49.65 \\
\hline & Tailings & 23.33 & 79.46 & 56.77 & \\
\hline \multirow[t]{2}{*}{0.57} & Concentrate & 78.10 & 17.34 & 43.25 & 53.10 \\
\hline & Tailings & 21.90 & 81.14 & 56.75 & \\
\hline \multirow[t]{2}{*}{0.65} & Concentrate & 79.26 & 21.19 & 49.98 & 44.09 \\
\hline & Tailings & 20.74 & 81.04 & 50.02 & \\
\hline \multirow[t]{2}{*}{0.87} & Concentrate & 78.12 & 20.28 & 45.49 & 50.04 \\
\hline & Tailings & 21.88 & 86.75 & 54.51 & \\
\hline
\end{tabular}

Note Diesel dosage is $2.87 \mathrm{~kg} / \mathrm{t}$, MIBC dosage is $0.65 \mathrm{~kg} / \mathrm{t}$, froth depth is $600 \mathrm{~mm}$, superficial air velocity is $0.78 \mathrm{~cm} / \mathrm{s}$, head ash of coal is $34.60 \%$ 
Table 10 Effect of froth depth on column flotation of coal

\begin{tabular}{|c|c|c|c|c|c|}
\hline $\begin{array}{l}\text { Froth depth } \\
(\mathrm{mm})\end{array}$ & Product & Yield (\%) & $A_{\mathrm{ad}}(\%)(\%)$ & Ash distribution (\%) & EI \\
\hline \multirow[t]{2}{*}{500} & Concentrate & 78.53 & 21.13 & 48.70 & \multirow[t]{2}{*}{45.24} \\
\hline & Tailings & 21.47 & 81.41 & 51.30 & \\
\hline \multirow[t]{2}{*}{600} & Concentrate & 78.10 & 17.34 & 43.25 & \multirow[t]{2}{*}{53.10} \\
\hline & Tailings & 21.90 & 81.14 & 56.75 & \\
\hline \multirow[t]{2}{*}{700} & Concentrate & 76.02 & 21.10 & 47.26 & \multirow[t]{2}{*}{43.53} \\
\hline & Tailings & 23.98 & 74.65 & 52.74 & \\
\hline \multirow[t]{2}{*}{800} & Concentrate & 79.35 & 16.41 & 44.54 & \multirow[t]{2}{*}{49.21} \\
\hline & Tailings & 20.65 & 78.52 & 55.46 & \\
\hline \multirow[t]{2}{*}{900} & Concentrate & 70.78 & 14.50 & 31.48 & \multirow[t]{2}{*}{58.30} \\
\hline & Tailings & 29.22 & 76.45 & 68.52 & \\
\hline
\end{tabular}

Note Diesel dosage is $2.87 \mathrm{~kg} / \mathrm{t}$, MIBC dosage is $0.65 \mathrm{~kg} / \mathrm{t}$, superficial feed velocity is $0.57 \mathrm{~cm} / \mathrm{s}$, superficial air velocity is $0.78 \mathrm{~cm} / \mathrm{s}$, head ash of coal is $34.60 \%$

Table 11 Effect of pulp density on column flotation of coal

\begin{tabular}{lllll}
\hline $\begin{array}{l}\text { \% Solids } \\
\text { by weight }\end{array}$ & Product & Yield $(\%)$ & $A_{\text {ad }}(\%)$ & Ash distribution $(\%)$ \\
\hline 4.76 & Concentrate & 72.18 & 14.83 & 35.44 \\
& Tailings & 27.82 & 70.09 & 64.56 \\
9.09 & Concentrate & 78.10 & 17.34 & 43.25 \\
& Tailings & 21.90 & 81.14 & 56.75 \\
13.04 & Concentrate & 87.94 & 20.14 & 66.53 \\
& Tailings & 12.06 & 73.88 & 33.47 \\
& Concentrate & 63.17 & 19.50 & 33.36 \\
& Tailings & 36.83 & 66.80 & 66.64 \\
\hline
\end{tabular}

Note Diesel dosage is $2.87 \mathrm{~kg} / \mathrm{t}$, MIBC dosage is $0.65 \mathrm{~kg} / \mathrm{t}$, froth depth is $600 \mathrm{~mm}$, superficial feed velocity is $0.57 \mathrm{~cm} / \mathrm{s}$, superficial air velocity $0.78 \mathrm{~cm} / \mathrm{s}$, head ash of coal is $34.60 \%$

ash forming particles might be entrained into the froth phase. If there is no enough froth depth, these particles will be carried along with the clean coal and thus the quality may be affected and the froth depth of $600 \mathrm{~mm}$ is optimized for further experiments.

It could be seen from the above results that the clean coal yield reduced at higher froth depths. This could be due to froth drop back into slurry phase across the froth/slurry interface at relatively higher froth depth. At the same time the ash content in the clean coal is reduced gradually as the froth depth increases.

\subsubsection{Effect of feed \% solids (pulp density)}

In order to examine the effect of pulp density on the flotation of coal, tests were conducted at various pulp densities and the results of the same are given in Table 11.
The decrease in selectivity in flotation of clean coal was observed when the pulp density is increased from $4.76 \%$ to $16.67 \%$. But the efficiency of separation is better between $5 \%$ and $9 \%$ solids.

\section{Conclusions}

A non-coking coal of vitrinite variety and analyzing $34.6 \%$ ash, $26.2 \%$ volatile matter, $1.3 \%$ moisture and $37.9 \%$ fixed carbon was subjected for flotation and column flotation studies. Concentrate/froth of $14.83 \%$ ash at $72.18 \%$ yield could be achieved at optimum process parameters such as 'mesh of grind' $\left(\mathrm{d}_{80}: 44 \mu \mathrm{m}\right)$, collector dosage (diesel: $2.87 \mathrm{~kg} / \mathrm{t}$ ) and frother dosage (MIBC: $0.65 \mathrm{~kg} / \mathrm{t}$ ) and flotation column operating parameters like froth depth $(600 \mathrm{~mm})$, superficial feed velocity $(0.57 \mathrm{~cm} / \mathrm{s})$, 
superficial air velocity $(0.78 \mathrm{~cm} / \mathrm{s})$ and feed pulp consistency of $9 \%$ solids by weight. Out of these parameters, froth depth and slurry feed percent solids have significant effect on the process. The concentrate produced by this process is suitable as fuel for IGCC in coal-to-electricity route.

Acknowledgments The authors are thankful to The Director, CSIRNML for his encouragement and support for publishing this work.

Open Access This article is distributed under the terms of the Creative Commons Attribution 4.0 International License (http://crea tivecommons.org/licenses/by/4.0/), which permits unrestricted use, distribution, and reproduction in any medium, provided you give appropriate credit to the original author(s) and the source, provide a link to the Creative Commons license, and indicate if changes were made.

\section{References}

Andrew Mohns C (1997) Effect of particle size on coal flotation kinetics (PhD thesis). Queen's University, Kingston:pp1-4

Arnold BJ, Aplan FF (1989) The hydrophobicity of coal macerals. Fuel 68(5):651-658

Bensley CN, Nicol SK (1985) The effect of mechanical variables on the flotation of coarse coal. Coal preparation 1:189

Boylu F, Laskowski JS (2007) Rate of water transfer to flotation froth in the flotation of low-rank coal that also requires the use of oily collector. Int J Miner Process 83:125-131

Brady GA, Gauger AW (1940) Properties of coal surfaces. J ind eng chem 32:1599-1604

Dey S, Pani S (2012) Effective processing of low-volatile medium coking coal fines of Indian origin using different process variables of flotation. Int J Coal Prep Util 32:253
Ding LP (2009) Investigation of bituminous coal hydrophobicity and its influence on flotation. Energy fuels 23:5536-5543

Gosiewska A, Drelich J, Laskowski JS, Pawlik M (2002) Mineral matter distribution on coal surface and its effect on coal wettability. J Colloid Interface Sci 247(1):107-116

Khoury DL (1981) Coal Cleaning Technology. NDC, Park Ridge

Koca S, Bektas Y, Koca H (2010) Contact angle measurement on lignite surface. Proceedings of the XXV International Mineral Processing Congress (IMPC) Brisbane 2049

Konar BB, Banerjee SB, Chaudhuri SG, Choudhury A, Das NS, Sen Kalyan (1997) In: Coal Preparation. Allied Publishers Ltd New Delhi, CFRI Golden jubilee monograph

Laskowski JS (2001) Coal flotation and fine coal utilization. Elsevier Science, Amsterdam, p 225

Mukherjee AK, Chatterjee CN, Ghose S (1982) Coal Resources of India:it's formation, distribution and utilisation. Fuel Sci Technol 1:19-34

Peng FF (1996) Surface energy and induction time of fine coals treated with various levels of dispersed collector and their correlation to flotation responses. Energy fuels 10:1202-1207

Shobhana Dey, Gyana Manjari Paul, Santosh Pani (2013) Effective flotation of weathered coal using frother blend. In: Coal preparation technology CSIR - CIMFR Jharkhand

Vasumathi N, Vijaya Kumar TV, Subba Rao S, Prabhakar S, Bhaskar Raju G, Shiva Kumar S, Raman Uma (2013) Eco-friendly and cost effective reagent Sokem 590C for coal flotation. Int J Eng Res 2(7):418-433

Yenigalla GR (2013) Coal Beneficiation: A road to clean coal Technology. In CSIR - CIMFR Jharkhand India: Coal Preparation Technology Proceedings

Yoon RH, Luttrell GH, Asmatulu R (2002) Extending the upper particle size limit for coal flotation. J South African Inst Mining Metallurgy 102(7):411-415 